\title{
Designing Year 12 strategy training in listening and writing: from theory to practice
}

Article

Accepted Version

Graham, S. and Macaro, E. (2007) Designing Year 12 strategy training in listening and writing: from theory to practice.

Language Learning Journal, 35 (2). pp. 153-173. ISSN 17532167 doi: https://doi.org/10.1080/09571730701599203 Available at https://centaur.reading.ac.uk/12561/

It is advisable to refer to the publisher's version if you intend to cite from the work. See Guidance on citing.

To link to this article DOI: http://dx.doi.org/10.1080/09571730701599203

Publisher: Taylor \& Francis

All outputs in CentAUR are protected by Intellectual Property Rights law, including copyright law. Copyright and IPR is retained by the creators or other copyright holders. Terms and conditions for use of this material are defined in the End User Agreement.

www.reading.ac.uk/centaur

\section{CentAUR}


Central Archive at the University of Reading

Reading's research outputs online 


\section{Designing Year 12 strategy training in listening and writing: from theory to practice}

Suzanne Graham, University of Reading

Ernesto Macaro, University of Oxford

\section{$\underline{\text { Abstract }}$}

This article outlines some of the key issues involved in developing a programme of strategy training for learners of French, in listening and in writing. It highlights the theoretical perspectives and research findings on listening and writing that informed the selection of strategies to teach learners and thence the development of appropriate materials. Examples of these materials are given as well as advice regarding their use. The article concludes with suggestions for how strategy training might be incorporated into teachers' own work with learners.

\section{$\underline{\text { Introduction }}$}

Research and anecdotal evidence suggest that, as learners of French move into the post-16 phase, they experience particular difficulties with listening and writing (Graham, 1997, 2002, this volume). It is in these areas therefore that learners seem to be the most in need of an approach that will provide them with the tools to improve their learning. The purpose of this article is to give a description of a strategy training ${ }^{1}$ project in these two skills for year 12 students and to give examples of the kinds of activities and materials that were used. The whole project was funded by the Economic and Social Research Council. 
Little research has been carried out into the effects of strategy training for listening comprehension. Furthermore, the few studies that have been completed in this area have produced mixed results regarding the benefits for students receiving training against a comparison group receiving none. Some studies indicate no improvement in students' listening after strategy training (e.g. Ozeki, 2000), others slight improvement (e.g. O’Malley, Chamot, Stewner-Manzanares, Russo and Küpper, 1985; Seo, 2000), and still others, significant improvement in some areas of listening only (Kohler, 2002; Thompson and Rubin,1996). These studies also provided training over different periods of time, with learners of different proficiency levels. Thus few firm conclusions can be drawn about what the key elements of successful listening strategy training might be, although the-two projects that appear to have been morethe mest successful, Thompson and Rubin (1996) and Kohler (2002), focussed more sharply on metacognitive strategy development, including strategy evaluation (both studies) and comprehension monitoring (Thompson and Rubin, 1996 only).

In writing, there has been considerable research into the processes (planning, drafting, re-drafting) that writers go through in order to achieve their end-product. However, very little attention has been paid to the "formulation" stage of writing. This stage is the moment when the writer attempts to convert an idea into actual language and has a number of choices available to him or her. Even less research has been conducted into how learners might be helped to adopt more effective strategies for the formulation stage, and certainly none has taken place in contexts similar to that of post-16 in England. One of the choices that learners need to make in the formulation stage is whether to think of words and phrases in their first language (L1) or to try to 
retrieve foreign language (L2) words or phrases stored in long term memory. Some research on the question of L1 use has been conducted (see Macaro, this volume) and the evidence suggests that at all levels some use of L1 for formulating language is made, and that it can be a useful strategy if combined with other strategies. Very little research has been carried out on less-advanced writers of French and no training programmes have been conducted in contexts similar to that of post-16 in England. Thus little is known about what teachers might do to help these students write better.

As Grenfell and Erler (this volume) explain, there exists a widely accepted model of strategy training that leads learners from awareness-raising, through modelling and practice of strategies, to evaluation of strategies that have been developed. This model was applied in the present project, with modifications. The training was delivered to ten schools over a period of seven months, with schools divided into High' and 'Low' scaffolding groups. As explained fully in Graham (this volume, also giving details of student numbers), there was more emphasis on awareness-raising, regarding the utility of strategies, for the High Scaffolding (HS) schools. The students in these schools also received formative feedback on their strategy use and evaluated much more fully the strategies they had been taught than the Low Scaffolding (LS) schools did. This evaluation included reflective diaries, which also involved the action planning for further strategy use, along the lines suggested by Grenfell and Harris (1999). Thus the metacognitive element was greater for HS schools. For students in all schools, guidance in strategy deployment and reminders to use strategies were incorporated into the materials we produced, in order to help learners internalise the strategies presented. The L2 was used as far as possible in materials, but it was supplemented by L1 glosses or explanations when the L2 was felt to pose a potential 
barrier to understanding (see O'Malley and Chamot, 1990: 183, for a discussion of this issue). Seven training activities were provided for listening and five for writing, and these were used by teachers between October 2004 and March 2005.

After initial input from researchers, much of the rest of the strategy training was delivered by the normal class teacher. We were keen to incorporate the strategy training into the learners' usual classes, as research (e.g. Schwartz, 1992) suggests that this approach is more effective. However, one of the problems we faced was the nature of the Year 12 curriculum, which leaves essentially only eight months of teaching time (less the time spent on 'mock' examinations). Teachers are also focussed on covering particular topics and preparing learners for certain task-types in the examination. In retrospect, it may have been too ambitious to select both listening and writing for strategy training over seven months. Research suggests that time is needed for learners to gain sufficient practice in using strategies, before they become automatic (O’Malley et al, 1985). At Key Stage 3, where there are fewer pressures from examinations, it may be possible to focus on two skills at once, with learners then able to continue working with strategies over a longer period of time.

Our decisions about which strategies to include in the training were informed by 1) our knowledge of the literature on listening and writing strategy research, and 2) an earlier phase of our study which attempted to find out how Year 12 students write and listen in French and whether particular clusters of strategies are more closely associated with successful writing and listening than others. We also wanted to select strategies that would help learners with the particular problems raised by similar learners in Phase 1. This approach, matching strategies to problems, would, it was 
hoped, make students more receptive to strategy training, as research suggests that not all learners react favourably to it (e.g. Wenden, 1987). More details regarding strategies for listening and writing are given below.

This article seeks to give insights into how we designed the strategy training used in the project. We do not report on the success or otherwise of the training because of lack of space and because our analyses are still at an early stage. Nevertheless, our early impressions are that, at least in listening, the groups who received the intervention did make substantial improvements. A number of publications are in progress which will give full statistical results for the project.

We now provide, under each skill, our reasons for adopting a particular training approach, an outline of how we went about it and some examples of materials used.

\section{Listening}

$\underline{\text { Rationale for our training approach and selection of strategies to be taught }}$

Research suggests that a number of strategies are important for effective listening,

Research suggests that a number of strategies tend to be used by more effective tisteners, including predicting what the passage might be about (Goh, 1998), deciding to 'listen out for' certain words or phrases (O’Malley, Chamot and Küpper, 1989); monitoring or checking that one is in fact understanding or has made the correct interpretation (Goh, 2002, Young 1996), and inferring the meaning of unknown words with the help of different clues (Goh, 2002). Our decision regarding the most 
important strategies for Year 12 learners of French was also based on the strategies and problems we observed another group of students using while they were listening, in Phase 1 of the project. These learners completed individual listening interviews, in which they listened to a text and had to answer a set of multiple choice questions. As they did so, they reported on the strategies they had used to understand the text and select their response. Problems and strategies identified in this phase included:

- Ineffective use of prediction (e.g. simply listing words that might be heard, without considering the overall theme of the topic)

- Lack of monitoring (to check if items predicted, and then heard, were in fact the correct answer)

- Ineffective use of context or prior knowledge of the topic to work out the meaning of unknown words (either under-using or over-using this strategy, and with little monitoring)

- Over-reliance on words that were perceptually salient (which students called 'key words', even if they were not important for the meaning of the text)

- Establishing word boundaries and identifying familiar words

Thus it was decided that strategic input would be most beneficial in the following areas: effective prediction formation, followed by 'checking out the evidence' for predictions made, i.e. monitoring; identifying real key words; working out the meaning of unknown words; strategies for recognising familiar words and for recognising word boundaries. We thus included both cognitive and metacognitive strategies, the latter being particularly important for effective language learning (Graham, 1997; Macaro, 2001). In terms of the level of difficulty of various 
strategies, Rubin and Thompson (1992) comment that ‘top-down' strategies such as prediction that help learners gain 'a handle' on what the text is about, are easier than 'bottom-up' strategies (such as work on word boundaries) for listening comprehension. This principle guided the order in which we presented strategies as far as possible, with a lot of work done at the beginning of the project on predictions (not all of which is described here). However, Rubin and Thompson (1992) also point out that authentic texts rarely make it possible to focus on just one strategy at a time, which we also found to be the case.

\section{Carrying out the training in listening}

\section{$\underline{\text { Predictions and finding the 'real' key words }}$}

Another problem in designing listening strategy training material is that it is very

difficult for the teacher to 'model' listening strategies through thinking aloud, because listening is a rapid, unobservable process. Therefore very detailed activities were devised which, it was hoped, would guide learners through the processes that we wanted to model.

This is illustrated in the following activity. The text (see Appendix 1 for strategy sheet) was one normally used by one of the project schools for the topic of education. It took the form of an interview with a number of French students on an exchange at a UK university. An initial reading of the transcript suggested that the main difficulties learners would have would be identifying key information from a lengthy text with a number of different speakers. It also contained several figures and dates, which are 
often problematic in L2 listening. On the other hand, there were a number of features in the text that learners could make use of to increase their understanding: the interviewer often repeated or paraphrased what the interviewees had said, thus giving listeners a second chance to understand the original utterance; 'discourse marker phrases' were used to signal when key information was coming up. The topic was one which was within Year 12 students' realm of experience and they therefore had some prior knowledge which they could use. They had already received some strategy instruction on prediction prior to the work done on this text.

The first activity, therefore, tries to stimulate learners' background knowledge of the theme of higher education and to prepare them for some of the vocabulary that they might hear in the spoken text, by asking them to read a related written text. It asks them to think about how the words in the written text might be pronounced. At the same time, learners are asked to try to predict likely themes that will be discussed in the spoken text. They brainstorm some likely vocabulary that they might hear, but are also reminded to try to think of alternative ways of saying the same thing. This then is the preparation phase. The next stage is for learners to listen to the whole text and try to establish which of their predicted themes actually came up in the text - to help them realise that what one expects to hear does not always materialise.

The next section of the task is designed to help learners establish 'signposts' within a spoken text, the elements that break it down into comprehensible parts and indicate those aspects which contain key information. Learners are reminded that 'key' i.e. important parts of a passage are often repeated, summarised or introduced by discourse marker phrases such as 'Donc, Attendez, Alors'. The questions on the 
strategy sheet also prompt them to think about the questions that will be posed by the interviewer in the passage, so that they will be more easily able to identify where the information they need to find out will be located.

The last section of the strategy sheet asks learners to think about which strategies they have used and which they found the most useful. This evaluation is vital if learners are to be motivated to retain strategies and integrate them into their listening repertoire. They need to be able to identify which strategies worked for them so that they will be encouraged to try them on subsequent listening passages.

Ideally, such a guided exercise would be followed up by a similar passage but without the structured strategy-based activities outlined above. Students should be encouraged to use the strategies they have practised but more independently, again followed by an evaluation of the strategies used and which were the most effective.

\section{Focussing on sound patterns and intonation}

The strategies outlined above need to be combined with activities which will help learners to overcome certain fundamental problems with perceiving words and phrases in what may seem like an unbroken stream of language. From our work with learners in the first phase of the research project it, was clear that Year 12 learners experience a number of difficulties in recognising words that they would know if they saw them written down and in identifying where phrases start and end. Research with Key Stage 3 learners by Erler and by Woore (both this volume) suggests that work on phoneme/grapheme correspondences can help with reading and writing and the same beneficial effect for listening with our older learners was anticipated. 
With this in mind, we asked learners to carry out what might be called 'ear training'. We began with activities adapted from an AS course book (Pillette and Clarke, 1999), but similar ones can be found in other texts. Learners heard four pairs of vowel sounds in French (e.g. en on en on ) and had to match these with four pairs written down. They then listened to the groups of sounds again, without looking at the written form, and were asked to try to visualise them, before writing down what they heard. Similar visualisation strategies were then practised with a group of words containing problematic vowel sounds (e.g. devant, devons), where learners were asked to: 1. anticipate what the words in question would sound like before they heard them; 2. Listen to the words while looking at their written form; 3. Listen again, without looking at the written form but this time trying to visualise the words.

After this practice, learners were advised to try to visualise problem sounds while listening, working with transcripts from other tapes. The following is an extract from the strategy sheet used, based on advice given in Pillette and Graham (2000).

INSERT Figure ...1..HERE - Strategies for identifying sounds

Following on from this, we included activities to draw students' attention to differences in intonation patterns between French and English. While in English, the position of the stressed syllable varies from word to word (e.g. finger; questionnaire), and can be changed if the speaker wants to emphasise something, French has a much 'flatter' intonation pattern, which can cause problems for speakers of English. It is not completely flat, however, and there is a slight stress on the last 
syllable of sense-groupings, followed by a slight pause. Awareness of this can help listeners to break sentences up into more manageable chunks. To help learners understand this better, we used an activity from Pillette (1998) which asks learners to locate the end of the sense-grouping in a series of sentences, e.g.

La grande majorité des Français trouve qu'il y a trop de jeux télévisés

Segmenting words and phrases in a continuous text rather than in individual sentences is more difficult, however, so a further activity was devised (by Robert Vanderplank, at the University of Oxford). This used a passage about a tragedy in the Alps (from Corless, Corless and Gaskell, 1990). In order to draw learners' attention to the end of sense-groupings, a gong sound was inserted where there was a slight break in the passage. Learners were asked to try to write down the phrase that immediately preceded the gong (the recording then restarted with this phrase). The purpose of this was to focus learners' attention not only on the intonation pattern at the end of sense groupings but also on potentially problematic phrases so that they might try to visualize all the different sound-writing correspondences that there might be. The next activity then presented them with various possibilities for what they might have heard before the gong sound, and asked them to select the most appropriate, as in this example:

INSERT Figure 2 HERE: Extract from an activity for segmenting words and phrases 
This required learners to focus on the way in which individual words can sound different when they are spoken as part of a phrase, because of such factors as liaison and elision. Teachers were advised to encourage learners to use the visualisation strategies outlined in the previous set of listening tasks, and to think about the following when deciding which option was correct:

- the local and the global context-i.e. the context of the passage as a whole, and of the sentence/phrase preceding and following the item in question - does the option they have chosen fit in with this?

- their knowledge of grammar - i.e. is the singular 'du' possible with a plural noun?

\section{Writing}

\section{$\underline{\text { Rationale for our training approach }}$}

As we outlined in our introduction, our main interest was in the "formulation" strategies that students were using rather than in their planning or their monitoring, checking and re-drafting. Our phase 1 data suggested that students were having major problems with turning ideas into French. The most common approach was to think of a word they knew (or one they had looked up in a dictionary) and try to create a sentence round it. This made them deploy a very limited set of strategies. Although we wanted to focus on formulation, we found it impossible to isolate formulation 
strategies from planning and monitoring. Firstly, planning or not planning before writing affects formulation as does the type of planning. For example, if writers launch into writing without planning they are, we hypothesize, generating their ideas as they go along and this may cause them to follow paths fraught with problems related to insufficient vocabulary and grammar. If writers plan in L1 they are more likely to come up with "higher level" ideas than if they "mind-map" in L2. Again this will affect the formulation stage of their writing in that higher level ideas may well produce more interesting content but at the same time produce greater inaccuracy. In terms of checking and re-drafting, an earlier study of year 10 students (Macaro, 2001) suggested that, when limited amounts of writing were involved, the best monitoring and checking happened phrase by phrase or sentence by sentence.

As a result of this previous research and experience, we selected the writing strategies that feature in the training below. What follows makes the process of writing appear very linear. Of course, it is much more recursive than this, but it is presented in linear fashion for the sake of convenience.

\section{Carrying out the training on writing}

(1) The first strategy was "mind-mapping" (or "brainstorming"). This is a planning strategy, carried out before commencing writing. Our phase 1 data suggested this strategy was almost completely missing from the students' repertoire. The objective here was to encourage students to try to retrieve from long term memory any phrases that matched the task requirements. In this way, it was hoped that at least some thinking in French would occur. 


\section{INSERT FIGURE 3 HERE ("planning before writing" scaffolding sheet)}

(2) The second strategy was "evaluating the gap". Again this was a planning strategy that we wanted to encourage. The idea here is that, having done as much "mindmapping" as possible, the students then consider how much distance they still have to cover before they can respond to the task requirements. Inevitably, at this level of language learning, this strategy is thought through in L1. The ideas they came up with as a result of this strategy would have to be formulated via a number of strategy choices as in the next paragraph.

(3) At the actual point of formulation, students then had the following choice of strategies. The first strategy was "re-combining" a set phrase with another set phrase. For example, they might combine "il y a toujours" with "beaucoup de problèmes", two separate set phrases that they knew by heart. The second strategy was "restructuring" a set phrase, that is, changing some grammatical elements within it. For example, they might take the set phrase "il y a toujours" and try to turn it into a negative. The third strategy was "generating a phrase" (literally translating word by word). Of course, both while "evaluating the gap" and "formulating", students could also deploy an "avoidance" strategy, that is, choosing not to express the "too difficult idea" at all. However, if they had opted for "generating a phrase", this strategy could then be combined with a number of strategies for consulting a bilingual dictionary.

(4) Another strategy was "monitoring" the phrase students had formulated (either still in their heads or in first draft form). A full list of monitoring strategies is given in the 
example materials, but the ones we most focused on were: visual monitoring, auditory monitoring, backtranslating, and prompting a specific monitoring of grammar or vocabulary. By prompting a specific monitor is meant that the student "prompts or reminds" himself/herself that they have to monitor some aspect of their formulation.

For example they might prompt themselves to "check that they have included an_d auxiliary in the past tense".

\section{INSERT FIGURE 4 HERE (writing strategy check list)}

(5) Reacting to feedback. Research evidence suggests that students do not do very much with the comments or corrections that teachers provide on their written work (Cohen and Cavalcanti, 1990; Truscott, 1996). We wanted to encourage the students to engage in a very strategic way with this feedback. This was done in three ways. Firstly by getting fellow students to comment on the content of what they had written, encouraging the notion that writing is about communicating meaning. Secondly, by providing students with a clear practical task once they received the teacher's feedback on errors. Thirdly, by providing comments about their strategy use rather than only about the accuracy of what they had written.

\section{INSERT FIGURES 5 AND 6 HERE (peer feedback sheet; reacting to teacher}

\section{feedback sheet)}

For each of these writing strategies, or clusters of strategies, the research team provided feedback to the individual students on their strategic approach to the writing task. In order to do this, students were asked to hand in each stage in the writing 
process. So for example, they were asked to hand in the results of their "mindmapping" and then received feedback on just this strategy, for example:

You didn't do the brainstorming strategy. I think this will help to get your brain thinking about the topic more and also you will come up with some good set phrases that you can recombine with others or restructure....

The teachers agreed to reinforce this mind-mapping phase of writing throughout the intervention period. Particularly, what was being discouraged was mind-mapping in English! So they were required to do this under time pressure and without the use of a dictionary otherwise the whole purpose would be missed. Although thinking in French via the mind-map was usually commented on positively, we also wanted the students to extend themselves by using the "evaluating the gap" strategy, and thereby not constantly avoiding ideas:

I think your approach to not thinking in English very much is a good one at this sort of level of topic when you could avoid saying things that you didn't know how to say. However, when you come to write about more difficult topics you will inevitably have to do some thinking in English and then translating. So that's when the monitoring strategies will come in very useful.

What we were trying to encourage via the feedback on each stage was the orchestration of a number of strategies. Evaluating what is the best strategy to use at any particular time or with any sub-task is crucial and combining them is essential. As 
the last feedback comment suggests, the more thinking in L2 (via the mind-map) the less "specific prompt" monitoring the writer will have to do, but they may have to monitor visually or aurally, to make comparisons with their previous linguistic knowledge as to whether it looks or sounds right. Hence, we gave feedback on students' monitoring strategies according to the formulating strategies that they had adopted:

look at your phrase "comme aller au cinéma" (where there is a problem) what do you get if you backtranslate the whole sentence?

Try visual monitoring a bit more: does maintnent look right?

“en Birmingham" - did you really do an auditory monitoring on this? Does it sound right to you?

We also offered teachers an activity in the use of dictionaries because of the problems that students experience with the use of dictionaries. This activity focused on getting the students to evaluate more extensively what the dictionary had to offer and to be more critical about the way they made their look-up decisions.

\section{Difficulties experienced}


The Introduction to this article questions whether we were perhaps too ambitious in attempting strategy training in both listening and writing in Year 12. This concern is largely prompted by a number of difficulties that we experienced during the project.

The first of these was to do with the time taken for the strategy training. A number of critics of strategy training (Kellerman, 1991, Rees-Miller, 1993) have suggested that time would be better spent simply teaching the language. Supporters of strategy training $^{2}$ have repeatedly argued that the time taken up with training is more than made up for by the additional skills the learner can bring to the learning process and that it leads to greater learner autonomy.

Although we had endeavoured to provide activities that would fit in with normal AS topics, it was difficult to co-ordinate the topic used in the training material with the topic being studied by every class in every school. This meant that some teachers felt that it was not always easy to find space for the strategy training in lessons. They therefore saw it as "additional to language learning" rather than integrated. The ideal scenario would be for teachers to be able to design their own strategy-based material, using tasks and texts that they would normally be intending to use. For this to have been possible, however, would have required intensive training for the teachers and our time-scale (and research budget) could not incorporate this.

Linked to this problem was the students' perceptions of the activities in the training. They too sometimes communicated that it was taking up valuable time. That there was variation in the students' reactions may have been related to how convinced and committed the teachers were and hence how they presented materials to students. 
Students in the HS schools, however, who received feedback on their strategy use, reacted more favourably to the training, according to their responses in a questionnaire (not discussed here for reasons of space).

The second difficulty was the level of familiarity that some of the teachers had with strategy training. Some found the written instructions for exploitation provided with the material difficult to interpret. Face-to-face meetings would have helped in this respect. While it was possible to co-ordinate these for schools in one area of the project, elsewhere it proved impossible to find dates and times when all parties were happy to meet.

\section{Positive aspects of the training}

We would not want the above difficulties to give the impression that the project was unsuccessful. Rather, we would argue, it was "patchy". We have anecdotal evidence that, in at least two schools (both high scaffolding schools), the reaction of the students was extremely positive. Indeed, in one school an OFSTED inspector claimed to be delighted with the level of self-knowledge that the students displayed and that this may have largely been due to the project and the enthusiasm with which the teacher had embraced it.

\section{Guidelines for designing strategy training material}

If strategy training is to have a significant impact on learning in schools, then it needs to be something which teachers incorporate into their teaching on a long-term basis. It 
also needs to start much earlier than year 12 . We have some evidence from the project that by year 12 some learners were reluctant to change the way they had always gone about learning. After all, most of them would have been highly successful at GCSE.

Below are some suggestions as to how teachers might begin to devise their own strategy materials.

\section{$\underline{\text { Listening }}$}

1. Use texts and tasks which you would normally be using with your class so that learners accept the strategy training more readily.

2. Read the transcript and listen to the tape to try to anticipate what difficulties learners will have, beyond obviously unknown vocabulary. These may include: liaison and similar factors that make known words difficult to understand, or that make it more difficult for learners to detect the start and end of sense-groupings; a lengthy text in which the most important details.are not self-evident.

3. Be wary of over-emphasising the use of context or 'common sense' to work out the meaning of a text. This often leads learners to make erroneous assumptions and to ignore what the text actually says.

4. Start with simpler strategies such as predicting likely content and vocabulary, followed by 'checking out the evidence' -through attention to features such as negatives and adverbs.

5. Supplement such strategy work with 'ear training' that helps learners to break down the language they are hearing and gives them more mental processing space to concentrate on strategy use. 
6. Once you have introduced a strategy, remind learners to try it on other listening tasks. Gradually make these reminders less frequent, as learners need to be able to use strategies independently.

7. Always ask students to evaluate any strategies they have tried. They need to be able to appreciate the benefits of using a strategy if they are to apply it again. They also need to consider which strategies are the most appropriate for which kinds of tasks and texts.

8. Don't be disappointed if learners react negatively to strategy instruction, especially at the start. It is likely that just thinking about how they listen will be of some benefit for them.

9. Offer feedback on learners' strategy use.

\section{$\underline{\text { Writing }}$}

These suggestions are essentially aimed at year 12 but are applicable to less advanced students too.

(1) Make a decision to treat some of the AS topics differently. Instead of starting off with reading and listening on a topic, followed by exploitation and then, speaking and writing, start off with writing! Ask students to write about a topic they have not studied but which they have a familiarity with in English (for example, detention without trial) and tell them they have to do it with only a dictionary as a resource. They will probably freak out! Reassure them by telling them that you are carrying out an analysis of their needs. Encourage them to take risks. That way you will find out what their real language problems are rather than them masking their problems by "cutting and pasting" from textbooks, from worksheets, and from models of language provided in articles and so on. 
(2) Treat each stage in the writing process separately. Encourage students to think about and tell you about:

(i) how they plan their writing;

(ii) how they go from an idea to the first attempt at putting pen to paper (or fingers on keyboard);

(iii) how often they look words up in a dictionary;

(iv) how they monitor for mistakes - and here get them to differentiate "new mistakes" (where they are making hypotheses about what the French might be) and "personal mistakes" (the ones they know they make often);

(v) how they react to your feedback on their mistakes.

(3) Carry out activities related to dictionary look-up strategies. Early in year 12 students need to have gained confidence in using a bilingual dictionary.

(4) Ask students to evaluate how this different process of writing is helping them a) to become better writers, and b) to improve their vocabulary and grammar.

\section{Conclusion}

The ideas we have presented in this article are based on strategy related research which is emerging in listening and in writing. The research is by no means conclusive. However, it certainly indicates that there is something in the idea of teaching learners how to learn that can lead to success even though it may take up some time from the "normal teaching activities". There is still a long way to go before we, as authors, would feel confident about turning the above suggestions into recommendations, let alone that they should become national policy. Nevertheless, none of us, we venture, 
is happy with the current state of affairs with language learning in England. It is clear that we do need a radical re-think in what we are doing. The practical suggestions made in this article should be explored in a partnership between teachers, researchers, (and yes!) students. With modifications and refinements they may well offer a more cohesive way forward than other, less researched, initiatives. 


\section{Notes:}

1. The term 'instruction' is more commonly used in the international literature on learner strategies, rather than 'training'. We have, however, chosen to use the latter as it is more appropriate for the UK context of the article.

2. The thoughts and research of many such 'supporters' of strategy training are being brought together in a forthcoming publication (Cohen and Macaro). 


\section{Appendix A}

Prediction and finding the 'real' key words.

Students were given a written text, L'entrée aux études supérieures, then the following tasks, to be addressed in relation to the spoken text (an interview, from Thématique 4, Mary Glasgow, 1992):

1. Comment s'inscrire? Vous allez entendre trois étudiants français qui viennent de l'Université d'Aix en Provence, mais qui passent une année en Grande-Bretagne [...] Ils s'entretiennent avec Dominique, une journaliste, qui leur parle de la vie estudiantine en France. Écoutez-les se présenter.

3. Écrivez un résumé pour chacun des étudiants. Essayez d'incorporer les points suivants:

- Nôm/âge/année de naissance

- Détails du cursus

- Endroits où ils font leurs études

- Particularités 


\section{Accompanying strategy sheet}

\section{Identifier les 'mots clef' (i)}

Pour bien écouter, vous ne devez pas comprendre chaque mot. Cependant, vous devez savoir quels sont les véritables 'mots clef' (key words). Si vous vous préparez bien à l' écoute, c'est plus facile.

\section{1 - 'L'enseignement supérieur en France', Thématique 4.}

Lisez le texte, 'L'entrée aux études supérieures '. Vérifiez que vous comprenez la plupart du vocabulaire et essayez d'anticiper la prononciation (think about what it might sound like).

2

- Lisez Question 1 ('Comment s'inscrire?') avant d' écouter la cassette.

- Répondez aux questions suivantes:

\section{a) On va parler de quoi, à votre avis? Notez vos idées:}

b) Quel type de vocabulaire allez-vous peut-être entendre ? Notez vos idées (n'oubliez pas de penser à des synonymes aussi):

3

- Maintenant, écoutez la cassette pour comprendre l'essentiel du passage (to get the gist of it)

- Cochez $(\sqrt{ })$ les prédictions qui étaient correctes. Mettez une croix $(\mathrm{X})$ si elles n'étaient pas correctes.

\section{Identifier les 'mots clef' (ii)}

Comment identifier les 'mots clef'? Faites attention:

- à la répétition ou à la paraphrase des mots importants par celui qui parle (by the speaker).

- aux discourse marker phrases qui indiquent qu'on va parler de quelque chose d'important (donc, enfin, etc.). Ces phrases sont souvent suivies par une pause.

- aux questions et aux exercices qui accompagnent le texte.

1 Lisez Question 3 à la feuille 'L'enseignement supérieur en France' et répondez aux questions suivantes: 
a) Quelles questions la journaliste va-t-elle poser? Quels mots va-t-elle utiliser pour poser ces questions? (par exemple, comment dire 'when', 'how'?) Notez vos idées ici:

b) Quelles sortes de réponses les étudiants vont-ils donner? (par exemple, comment parler de son année de naissance) (how might they say when they were born?) Notez vos idées ici:

2

Maintenant, écoutez la cassette encore une fois. Faites attention à tout ce que vous avez anticipé (questions, réponses, vocabulaire), faites attention aux 'discourse marker phrases' pour guider votre compréhension. Essayez de répondre à Question 3 à la feuille 'L'enseignement supérieur en

France'. Notez vos réponses ici et à la page suivante:

Quelles stratégies avez-vous utilisées pour identifier les mots clef? Cochez! $(\sqrt{ })$

J'ai

$\square$ fait des prédictions

$\square$ anticipé la prononciation des mots

$\square \quad$ pensé à des synonymes

J'ai fait attention

$\square$ à la répétition ou à la paraphrase
aux 'discourse marker phrases'
aux questions et aux exercices qui accompagnent le texte
$\square$ à ce que j'ai anticipé (questions, vocabulaire, réponses)

Soulignez les stratégies les plus utiles! 


\section{$\underline{\text { References }}$}

Cohen, A.D. and Cavalcanti, M.C. (1990). Feedback on compositions: teacher and student verbal reports. In B. Kroll (ed.) Second language writing: Research insights from the classroom. Cambridge: Cambridge University Press.

Cohen, A. D. and Macaro, E. (eds.) (forthcoming). Language learner strategies: 30 years of research and practice. Oxford: Oxford University Press.

Corless, F., Corless, H. and Gaskell, R. (1990). Signes du temps: Vécu. London : Hodder and Stoughton.

Goh, C.C.M. (1998). How ESL learners with different listening abilities use comprehension strategies and tactics. Language Teaching Research, 2/2, 124-147.

Goh, C.C.M. (2002). Exploring listening comprehension tactics and their interaction patterns. System, 30, 185-206.

Graham, S. (1997). Effective Language Learning. Positive Strategies for Advanced Level Language Learning. Multilingual Matters Ltd., Clevedon.

Graham, S. (2002). Experiences of learning French: a snapshot at Years 11, 12 and 13, Language Learning Journal, 25, 15-20.

Graham, S. (2007) Learner strategies and self-efficacy: making the connection. Language Learning Journal, 35(1), 81-93. 
Grenfell, M. (2007) Language learner strategies research and modern foreign

language teaching and learning. Language Learning Journal, 35(1), 9-22.

Grenfell, M. and Harris, V. (1999). Modern languages and learning strategies in theory and in practice. London: Routledge.

Kellerman, E. (1991). Compensatory strategies in second language research: a critique a revision and some (non-) implications for the classroom. In R. Phillipson, E. Kellerman, L. Selinker, M. Sharwood-Smith and M. Swain (Eds.) Foreign and second language pedagogy research. (pp. 142-162). Clevedon: Multilingual Matters.

Kohler, B. D. (2002). The effects of metacognitive language learning strategy training on lower-achieving second language learners. PhD thesis, Brigham Young University.

Macaro, E. (2001) Learner strategies in second and foreign language classrooms. London: Continuum.

Macaro, E. (2007). Do near-beginner learners of French have any writing strategies? Language Learning Journal, 35(1), 23-35

New Roman

Formatted: Opening para., Line spacing: single, Widow/Orphan control Formatted: Font: Times New Roman, English (U.K.)

O'Malley, J.M. and Chamot, A.U. (1990). Learning strategies in second language acquisition. Cambridge: Cambridge University Press. 
O'Malley, J.M., Chamot, A.U. and Küpper, L. (1989). Listening comprehension strategies in second language acquisition. Applied Linguistics, 10/4, 418-437

O’Malley, J.M., Chamot, A.U., Stewner-Manzaneres, G., Russo, R.P. \& Küpper, L. (1985). Learning strategy application with students of English as a second language. TESOL Quarterly 19, 557-584.

Ozeki, N. (2000). Listening strategy instruction for female EFL college students in Japan. PhD thesis, Indiana University of Pennsylvania, The Graduate School and Research Department of English.

Pillette, M. (1998). Bridging the gap at 16+. London: Collins Educational.

Pillette, M. and Clarke, B. (1999). Objectif Bac 1. London: Collins Educational.

Pillette, M. and Graham, S. (2000). Objectif Bac 2. London: Collins Educational.

Rees-Miller, J. (1993). A critical appraisal of learner training: Theoretical bases and teaching implications. TESOL Quarterly 27/4, 679-89.

Rubin, J. and Thompson, I. (1992). Materials selection in strategy instruction for Russian listening comprehension. ERIC Document No. ED 349796. 
Seo, K. (2000). Intervening in tertiary students' strategic listening in Japanese as a foreign language. Unpublished dissertation: Griffith University, Australia.

Schwartz, A.M. (1992) The effects of interactive video training on listening techniques, metacognition, and attribution on the listening comprehension of second language video. Diss; Univ. of Maryland, 1992.

Thompson, I. and Rubin, J. (1996). Can strategy instruction improve listening comprehension? Foreign Language Annals, 29/3, 331-342.

Truscott, J. (1996). The case against grammar correction in L2 writing classes. Language Learning, 46, 2, 327-69.

Wenden, A. (1987). Incorporating learner training in the classroom. In A. Wenden and J. Rubin (Eds.) Learner strategies in language learning (pp. 159-168).

Englewood Cliffs, NJ: Prentice-Hall.

Young, M.C. (1996). Listening comprehension strategies used by university level Chinese students learning English as a second language. PhD thesis, University of Essex. 
Figures to be inserted in the text.

Figure 1. Strategies for identifying sounds

Problem - you can't identify sounds that you hear, even if they are in words that you would know if they were written down.

\section{Strategies to try:}

- Work on one sound at a time;

- Choose a transcript (maybe something you have listened to in class or at home, that you found difficult);

- Underline the words that contain the 'problem' sound;

- Repeat the exercises which we have just done:

$>$ read the transcript

anticipate what the underlined words will sound like

listen while reading the transcript

$>$ listen again, without the transcript, trying to visualise the underlined words 
Figure 2. Extract from an activity for segmenting words and phrases

1. Listen to the broadcast again. This time the broadcast will have no breaks and there are alternatives phrases or parts of a phrase provided for you to choose. Choose the one which you think best fits what you hear and the context.

1. a. Douze alpinistes

b. Du salpinistes

2. a. ayant été

b. et ont été

c. ayons étaient

3. a. son tombait

b. sont tombées

c. sentombaient 
Figure 3 . "Planning before writing" scaffolding sheet

Figure 4. A writing strategy check list.

Figure 5. An example of a 'Peer feedback' sheet.

Figure 6. An example of a 'Reacting to teacher feedback' sheet. 